\title{
Insects associated with exposed decomposing bodies in the Colombian Andean Coffee Region
}

\author{
Diana Grisales ${ }^{1,2}$, Magnolia Ruiz ${ }^{1} \&$ Silvio Villegas ${ }^{1}$
}

\begin{abstract}
${ }^{1}$ Grupo de Invetigación Jaime Sierra García, Facultad de Derecho, Universidad Cooperativa de Colombia, Calle 50 № 41-70, Medellín-Antioquia, Colombia. ochoa310@gmail.com; catamar@une.net.co; silviovillegasecheverry@yahoo.es

${ }^{2}$ Departamento de Zoologia, Universidade Federal do Paraná, Caixa Postal 19020, 81581-980 Curitiba-PR, Brazil.
\end{abstract}

\begin{abstract}
Insects associated with exposed decomposing bodies in the Colombian Andean Coffee Region. In Colombia, mainly classic forensic medicine methods were used to clarify crimes until 2004. However, other disciplines, including forensic entomology, started to be considered only after the New Accusatory System introduction in Bogotá and the Coffee Region in 2005. In order to provide tools for obtaining evidentiary material elements in judicial trials, it is presented here the succession of insects throughout the decomposition process of an exposed carcass of Sus scrofa Linnaeus 1758 (Suidae) and the Occurrence Matrix of colonizing species. This process was evaluated under ambient conditions in the Andean rural area of the city of Pereira, in the Mundo Nuevo district, located in a pre-montane Wet Forest area, from October to November 2006. A sampling period of 27 days and 3198 individuals were collected. We found these colonizing species in the following stages of decomposition: Lucilia eximia (Wiedemann, 1819) fresh; Hemilucilia semidiaphana (Rondani, 1850), Oxelytrum discicolle (Brullé, 1840), and Cochliomyia macellaria (Fabricius 1775) bloated; Chrysomya albiceps (Wiedemann 1819), Compsomyiops verena (Walker, 1849), Ophyra aenescens (Wiedemann, 1830) and Musca domestica Linnaeus, 1758 active; Fannia sp. advanced and Stearibia nigriceps (Meigen, 1826) remains. This study provides support tools to define the Post Mortem Interval that may be used by experts from government institutions and laboratories officially accredited.
\end{abstract}

KEYWORDS. Andean central mountain chain; forensic entomology; Post-Mortem Interval.

RESUMO. Insetos associados com corpos em decomposição na Região Cafeeira Andina Colombiana. Na Colômbia predominou até o ano 2004 a utilização da medicina forense como ferramenta que facilita o processo de esclarecimento de fato criminoso. Contudo, outras disciplinas, entre elas a entomologia forense, começaram a ser utilizadas após o estabelecimento do Novo Sistema Acusatório no ano de 2005 em Bogotá e no Eje Cafetero (região cafeeira). Com o objetivo de gerar novas ferramentas dentro de processos judiciários, é apresentada aqui a sucessão de insetos em carcaça exposta de Sus scrofa Linnaeus 1758 (Suidae) e a Matriz de Ocorrência das espécies colonizadoras. O estudo foi realizado em zona rural da cidade de Pereira, localizada em floresta úmida prémontana, de outubro a novembro de 2006. O período amostral foi de 27 dias e foram coletados 3198 indivíduos, sendo as seguintes as espécies colonizadoras dos estágios de decomposição: Lucilia eximia (Wiedemann, 1819) fresco; Hemilucilia semidiaphana (Rondani, 1850), Oxelytrum discicolle (Brullé, 1840), Cochliomyia macellaria (Fabricius 1775) inchado; Chrysomya albiceps (Wiedemann 1819), Compsomyiops verena (Walker, 1849), Ophyra aenescens (Wiedemann, 1830) e Musca domestica Linnaeus, 1758 ativo; Fannia sp. avançado e Stearibia nigriceps (Meigen, 1826) restos. Este estudo gera ferramentas para definição do Intervalo Pós-Morte, que poderá ser utilizado por peritos de instituições do governo e laboratórios oficialmente acreditadas.

PALAVRAS-CHAVE. Cordilheira central andina; entomologia forense; Intervalo Pós-Morte.

Forensic entomology is a very important and frequently used tool for clarifying murders, suicides and other criminal acts. Seventy-two hours after death, this tool becomes the most accurate and sometimes the only tool for determining the time of death (Anderson \& VanLaerhoven 1996). Likewise, it may determine whether or not a body has been moved from one place to another, provide information about the place of death and thus, identify both the criminal and the victim (Anderson 2001).

A decomposing body is considered an ephemeral microhabitat that contains a high quality of nutrients. This exists for a short time, is small and is spatially disperse, where more than one generation of insects develops, which explains the diverse congregation of insects and other invertebrates that colonize it (Hanski \& Cambefort 1991). This is how carrion insects use the resource to support their growth, sustenance and reproduction (Schowalter 2000), colonizing the microhabitat for a limited time, and generating an entomological succession with a regular appearance pattern.

Knowledge of this succession pattern and development rates of each species found provides elements for estimating the Post Mortem Interval (PMI) (Benecke 1998 LaMotte \& Wells 2000).

In Colombia, mainly classic forensic medicine methods were used to clarify crimes until 2004. However, other disciplines, including forensic entomology, started to be considered only after the New Accusatory System introduction in Bogotá and the Coffee Region in 2005 (Law 906 of 2004) (Peñuela 2005). Despite being a recently applied tool in this country, entomological succession studies, growth curves and life cycles of forensically-important insect species and entomotoxicology studies have been conducted, all focused on obtaining relevant data for forensic entomology.

With regard to entomological succession, diverse works have been developed in Colombia using white pig carcasses in various altitudes and geographic areas (Wolff et al. 2001- 
Medellín, 1.500 m.; Pérez et al. 2005- Medellin urban area; Martínez et al. 2007- Chingaza, Andean Highlands, 3.035 m.; Segura et al. 2009- Bogota semi-rural area, 2.700 m.; D. Grisales (unpublished data) - Morrosquillo Gulf, dry tropical forest, $0 \mathrm{~m}$.. With regard to the identification of forensicallyimportant insect species in human corpses, the work by Barreto et al. (2002) in the city of Cali, located at $995 \mathrm{~m}$. above sea level. In the area of entomotoxicology, Wolff et al. $(2004,2006)$ conducted studies for quantifying and detecting Parathion and Propoxur, respectively, in forensicallyimportant species.

Studies of life history characteristics of diverse species used in forensic entomology, Camacho \& Usaquén (2004) calculated growth curves for the species Lucilia sericata (Meigen, 1826) in human liver in the city of Bogotá at 2.600 $\mathrm{m}$. Camacho (2005) identified the entomological succession and growth curves for Calliphora vicina Robineau-Desvoidy 1830 in Bogotá. The same was done for the species Lucilia eximia, Cochliomyia macellaria, Chrysomya albiceps, Chrysomya megacephala (Fabricius, 1794) and Calliphora nigribasis Macquart, 1851, bred in different altitudes by Vélez \& Wolff (2008). There are also notes on the behavior and distribution of forensically-important Calliphoridae in Colombia (Wolff \& Vélez 2007).

Considering the absence of forensic entomology studies in the Andean Coffee Region, the herein study is considered pioneer since it presents the succession of insects associated with the decomposition process of carcasses and the occurrence matrix (presence-absence) of forensically-important insects in the rural area of the city of Pereira, Risaralda Department. The study provides support tools to define the Post Mortem Interval that may subsequently be used by state institutions, such as the District Attorney's Office and the Medical Examiner's Office.

\section{MATERIAL AND METHODS}

The study area is located in the country house Finca La Acuarela (altitude of 1,550 m), in the Mundo Nuevo district $\left(4^{\circ} 49^{\prime} \mathrm{N} 75^{\circ} 42^{\prime} \mathrm{W}\right)$, rural area of the city of Pereira (Risaralda Department), known as part of Colombia's Coffee Belt. It has an average temperature of $21^{\circ} \mathrm{C}$, an average annual precipitation of $2,750 \mathrm{~mm}$, with periods of rain concentration in April-May and September-November. The wettest months are April and October $(812,6 \mathrm{~mm})$ and the driest is February (32 mm) (Aguilar \& Rangel 1994).

This area belongs to the Sub-Andean region $(1,100 \mathrm{~m}$. $2,500 \mathrm{~m}$ ), with great antropic activity on vegetable formations and the most inclined areas with relicts of forests (Aguilar \& Rangel 1994), belonging to the Pre-Montane Wet Forest life area, according to Holdridge (1987).

A $25-\mathrm{Kg}$ white pig carcass (Sus scrofa L.) was used as the decomposition model. The pig was killed with a stab to the heart (Martínez et al. 2007) in October 2006. Immediately following the death of the pig, it was placed in a metal cage (approx. $60 \mathrm{~cm} . \times 40 \mathrm{~cm}$. x $40 \mathrm{~cm}$.) to allow access of insects to the carcass and avoid the attack of carrion-eating vertebrates (Wolff et al. 2001). The cage was placed in an open field and sunlit area. The ecosystem that surrounded the collection site was mainly Guadua angustifolia Kunth, 1880 (Bambusaceae), Heliconia sp. (Musaceae) crop and a relict of Andean forest.

The samplings were carried out from October $9^{\text {th }}$ to November $3^{\text {rd }} 2006$, until the bodies were found in remains. Immature (eggs, larvae and pupae) and adult insects were collected during the first two weeks, three times a day (7:00, 12:00 and 17:00). When a remains stage of decomposition was recognized, a single collection was performed at 12:00, until the process ends. In each sampling, adult insects found flying over and/or posing on the body were collected with an entomologic net. Immature insects, other adults feeding on the body and those found under the body and on the ground were collected manually.

During each sampling, body, rectal, and ambient temperatures were recorded with a thermometer. Observable physical changes such as smell, swelling, liquids, gases, etc., were recorded. The carcass's weight was recorded in the morning when the first samples were made.

Adult insects were killed with ethyl acetate in glass jars and were mounted in the laboratory. The immatures were kept in $70 \%$ alcohol.

In order to know colonizing flies of the decomposition process, eggs found in the first three days were placed in 200 gr. of raw pork liver, in a plastic container with a screen filter top. Every 5 hours, a sample of 10 larvae was taken to the laboratory until completing the cycle. The samples were killed in 70\% alcohol (larvae) and in ethyl acetate (adults).

Both the adult and immature insects were identified with the keys of Borror et al. (1989), McAlpine et al. (1981, 1987), Dear (1985), White (1983), Greenberg \& Szyska (1984), Liu \& Greenberg (1989), Queiroz \& Carvalho (1987), Wells et al. (1999), Stehr (1987), Smith (1986) and Carvalho (2002). For identification of the immature insects, previous clarification and permanent mounting in Canada balsam was done. All of the samples collected were codified and deposited in the Laboratorio de Colecciones Entomológicas, Universidad de Antioquia (CEUA).

\section{Data Analysis}

To verify the statistical differences between abundance of individuals collected in each decomposition stage a Wilcoxon Matched Pairs Test (WMP) was performed, with the Statistica "v 7" program. Only data with $\mathrm{p}<0.05$ were considered significant.

With the information about the colonizing and the most abundant species in each stage of decomposition, an occurrence matrix (presence-absence) was done with immature dipterans and both immature and adult coleopterans, which are the most abundant and forensically important groups (Schoenley et al. 1992).

\section{RESULTS}

3,198 specimens (immature and adult) belonging to 5 orders, 20 families, 30 genera and 36 species were collected 


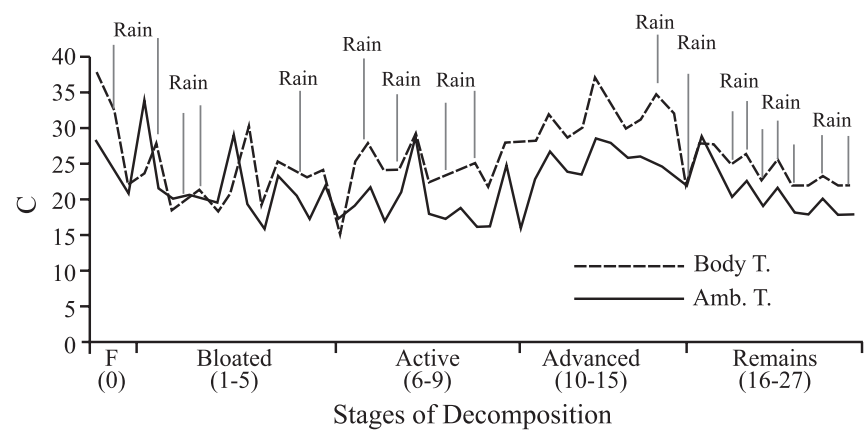

Fig. 1. Daily temperature variations related with stage of decomposition and rainy days.

(Table I). Of that amount, 2,837 individuals $(88.7 \%)$ were Diptera; 245 (7.66\%) Coleoptera; 60 (3.12\%) Hymenoptera; $52(1.6 \%)$ Acari; and $4(0.12 \%)$ Hemiptera. Within Diptera, 2 families predominated: Calliphoridae (69.13\%) and Muscidae (19.38\%). The remaining percentage corresponds to specimens belonging to Syrphidae, Fanniidae and Tephritidae (Table II, III).

Coleoptera was the second most abundant order and 4 families were the most abundant: Desmestidae (3.56\%), Silphidae (2.12\%), Staphylinidae (1.09\%) and Histeridae $(0.75 \%)$. (Tables II, III).

Stages of decomposition and entomological succession.

Five stages of decomposition were identified (fresh, bloated, active, advanced and remains) considering changes in body temperature, biomass reduction and physical changes in the pig carcass (Wolff et al. 2001; Martinez et al. 2007).

Abundance of individuals collected in each of the stages of decomposition showed significant differences between them $(\mathrm{p} \leq 0.000)$. Only the abundance between fresh and remains didn't show significant difference $(p=0,434757)$.

Fresh (Day 0).

In this stage, It could be observed a drop in body temperature from $38^{\circ} \mathrm{C}$ to $22^{\circ} \mathrm{C}$, almost reaching the ambient temperature level, which oscillated between $28.5^{\circ} \mathrm{C}$ and $21^{\circ} \mathrm{C}$, throughout the entire decomposition process (Fig. 1).

Very few flies were observed immediately following death, including the calliphorids Lucilia eximia and Cochliomyia macellaria, and Bithoracochaeta sp. (Muscidae). The initial egg masses were found in the mouth, 6 hours after death, and the eclosion of the eggs occurred 16 hours later. In the laboratory, it could be confirmed that these were $L$. eximia eggs. At the end of this stage, L. eximia larvae (L1 and L2) were found (Table III, IV). Epiponini wasps were found sucking the liquids drained from the wound.

\section{Bloated (Day 1 through Day 5).}

As the body temperature varied considerably during the days of heavy rain, ranging from 30.5 to $10^{\circ} \mathrm{C}$, there was a corresponding fluctuation in the degree of bloating of the carcass (Fig. 1). When this peak was reached, the temperature began to drop until reaching $15^{\circ} \mathrm{C}$, giving way the active stage. The carcass weight was constant through the beginning of the bloated stage (Fig. 3).

In spite of the use of cages to protect the carcass, vultures pecked at the carcass in its bloated stage. As a result, the body experimented an early escape of gases. However, new attacks by vultures could be avoided, allowing the decomposition process and the colonization by insects to continue. Presence of larvae (L2 and L3) of Calliphorids L. eximia, C. macellaria, Chrysomya albiceps, Hemilucilia semidiaphana, Chrysomya megacephala and Silphid Oxelytrum discicolle, as well as their adults and of the beetle Anotylus sp. (Staphylinidae) in the mouth, eyes, nostrils and anus of the carcass is highlighted (Table II, III, IV).

Adults of other species not collected in the Fresh phase were: calliphorids C. albiceps, C. macellaria; muscids Biopyrellia bipunctata, Musca domestica, Ophyra aenescens, Brontaea normata, Stomoxys calcitrans; hymenopterans Monomorium sp. (Formicidae), Melipona sp. (Apidae) and hemipterans Coreidae (Table I). In this stage, ovoposition by flies under the body, on the back, head, ears and anus increased. Predators began to be observed, ants of the genus Monomorium sp. and $O$. discicolle adults, nesting under the body. Epiponini wasps and the stafilinids Anotylus sp. and Paederomimus sp. (Table I) feeding on the carcass, eggs and larvae.

Active Decay (Day 6 through Day 9).

The highest peak in temperature $\left(29^{\circ} \mathrm{C}\right)$ occurred in the middle of the stage, during the colonization of larvae in the soft tissues of the entrails, with intermediate temperatures of $4^{\circ} \mathrm{C}$ with drops intermediate of up to $4^{\circ} \mathrm{C}$, due to the strong rains (Fig. 1). The weight of the carcass dropped drasticallty, going from $22 \mathrm{Kg}$ to $8 \mathrm{Kg}$ during the consumption of the tissues by the larvae (Fig. 2).

The intense larval activity in the entrails, expected at the beginning of this stage, was not recorded until the middle of his duration since the attack by vultures accelerated the exposure of the entrails but not the colonization of the larvae in those tissues. The presence of $3^{\text {rd }}$ instar larvae of the species Compsomyiops verena, Musca domestica and L1, L2 and L3 of Ophyra aenescens (Muscidae) (Table III) is worth noting. Other species and their immature stages, C. macellaria, $C$. albiceps, L. eximia and H. semidiaphana were collected (Table IV).

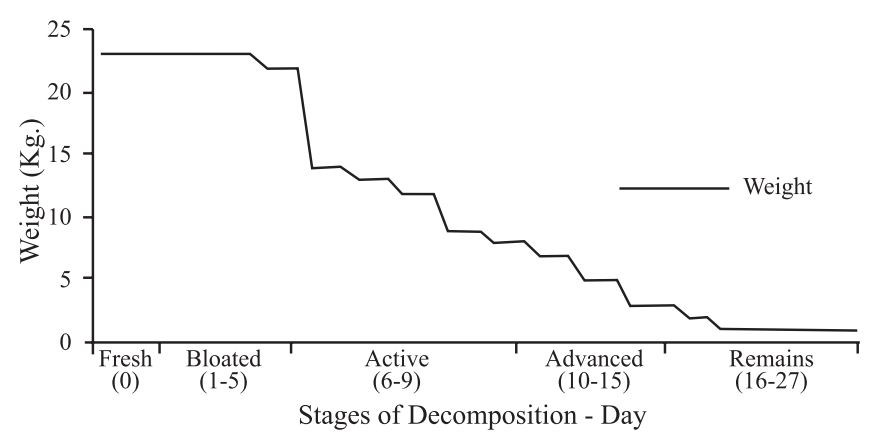

Fig. 2. Daily weight variations related with stage of decomposition. 
Table I. Succession of insects associated with exposed carcasses in Colombia's Andean Coffee Region.

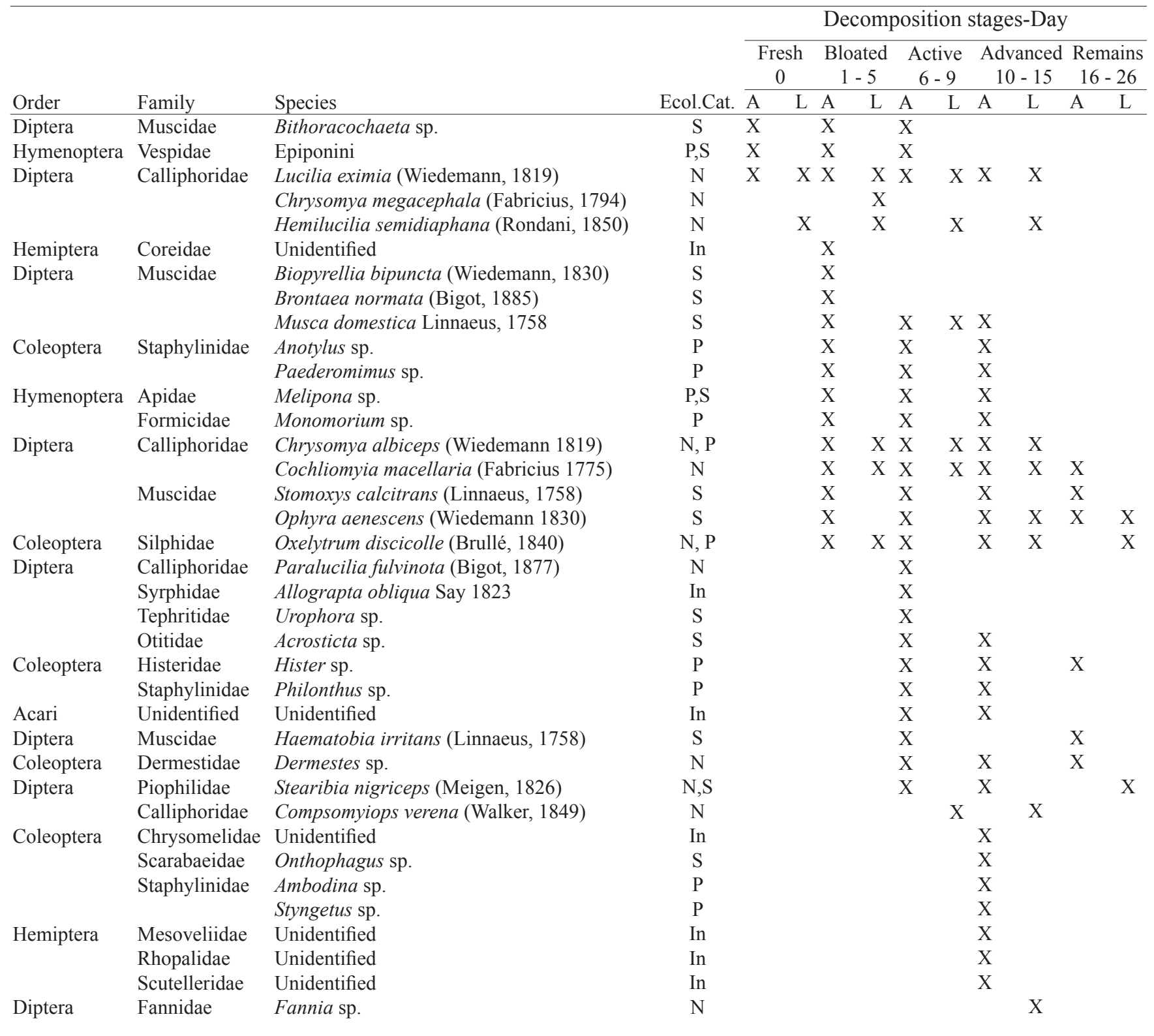

N: Necrophagous, S: Saprophagous, P: Predator, In: Incidental, A: Adult, L: Larvae.

Adults that were not found in the bloated phase: Coleopterans Dermestes sp. (Dermestidae) and Hister sp. (Histeridae); dipterans Paralucilia fulvinota (Calliphoridae), Stearibia nigriceps (Piophilidae), Acrosticta sp. (Ulidiidae), Allograpta obliqua (Syrphidae), Urophora sp. (Tephritidae), muscids Haematobia irritans, Stomoxys calcitrans, and mites unidentified (Table I). Migration under the body of $L$. eximia and $H$. semidiaphana larvae was observed at the beginning of the stage. C. albiceps migrated at the end and C. macellaria larvae were found approximately $1 \mathrm{~m}$. from the body. Histerids (Hister sp.) were found buried under the body and dermestids (Dermestes sp.) were found under the very dry skin.

Advanced Decay (Day 10 through Day 15).

The days were hot and sunny during this stage, which the body temperature fluctuated between $22^{\circ} \mathrm{C}$ and $37^{\circ} \mathrm{C}$ (Fig. 1). The weight went from $8 \mathrm{Kg}$ to $3 \mathrm{Kg}$ by the end of the stage, due to both the consumption of the remaining soft tissues by the larvae as well as to the dehydration of the remains (Fig. 2).

The number of Diptera larvae associated with the carcass decreased considerably and the diversity of the beetles increased (Table I, II). The presence of adult Ambodina sp. (Staphylinidae), as well as immature stages (L2, L3, prepupae, pupae) of C. macellaria, O. aenescens, L. eximia, C. albiceps, H. semidiaphana, Fannia sp. and Compsomyiops verena were worth noting (Table III, IV). The number of adult Diptera decreased, while the number of adult $O$. aenescens, which were found sucking liquids from the carcass and ovopositing under the body, increased. 
Table II. Percentage of adult dipterans and coleopterans of forensic importance collected in exposed carcass in Colombia's Andean Coffee Region at each stage of decomposition.

\begin{tabular}{|c|c|c|c|c|c|c|c|}
\hline Order & Family & Specie & $\begin{array}{c}\text { Fresh } \\
\text { (Day 0) }\end{array}$ & $\begin{array}{c}\text { Bloated } \\
\text { (Day 1-5) }\end{array}$ & $\begin{array}{c}\text { Active } \\
\text { (Day 6-9) }\end{array}$ & $\begin{array}{c}\text { Advanced } \\
\text { (Day 10-15) }\end{array}$ & $\begin{array}{c}\text { Remains } \\
\text { (Day 16-26) }\end{array}$ \\
\hline \multirow[t]{15}{*}{ Diptera } & \multirow[t]{4}{*}{ Calliphoridae } & Cochliomyia macellaria & 1,190 & 5,155 & 1,715 & 1,616 & 2,299 \\
\hline & & Chrysomya albiceps & 0,000 & 0,825 & 0,202 & 0,492 & 0,000 \\
\hline & & Lucilia eximia & 1,190 & 1,031 & 0,000 & 0,070 & 0,000 \\
\hline & & Paralucilia fulvinota & 0,000 & 0,000 & 0,101 & 0,000 & 0,000 \\
\hline & \multirow[t]{7}{*}{ Muscidae } & Bithoracochaeta sp. & 1,190 & 0,206 & 0,101 & 0,000 & 0,000 \\
\hline & & Ophyra aenescens & 0,000 & 1,649 & 0,807 & 4,076 & 0,000 \\
\hline & & Musca domestica & 0,000 & 1,237 & 0,303 & 0,632 & 0,000 \\
\hline & & Stomoxys calcitrans & 0,000 & 0,206 & 0,202 & 0,351 & 4,598 \\
\hline & & Biopyrellia bipuncta & 0,000 & 0,206 & 0,000 & 0,000 & 0,000 \\
\hline & & Brontaea normata & 0,000 & 0,206 & 0,000 & 0,000 & 0,000 \\
\hline & & Haematobia irritans & 0,000 & 0,000 & 0,101 & 0,000 & 1,149 \\
\hline & Piophilidae & Stearibia nigriceps & 0,000 & 0,000 & 0,303 & 0,422 & 0,000 \\
\hline & Syrphidae & Chamaesyrphus sp. & 0,000 & 0,000 & 0,303 & 0,000 & 0,000 \\
\hline & Otitidae & Acrosticta sp. & 0,000 & 0,000 & 0,101 & 0,070 & 0,000 \\
\hline & Tephritidae & Urophora sp. & 0,000 & 0,000 & 0,101 & 0,000 & 0,000 \\
\hline \multicolumn{8}{|c|}{ Coleoptera } \\
\hline & \multirow[t]{5}{*}{ Staphylinidae } & Anotylus sp. & 0,000 & 1,856 & 0,303 & 0,281 & 0,000 \\
\hline & & Philonthus sp. & 0,000 & 0,000 & 0,303 & 0,632 & 0,000 \\
\hline & & Paederomimus sp. & 0,000 & 0,000 & 0,202 & 0,000 & 0,000 \\
\hline & & Ambodina sp. & 0,000 & 0,000 & 0,000 & 0,422 & 0,000 \\
\hline & & Styngetus sp. & 0,000 & 0,000 & 0,000 & 0,202 & 0,000 \\
\hline & Silphidae & Oxelytrum discicolle & 0,000 & 0,206 & 3,633 & 1,968 & 0,000 \\
\hline & Dermestidae & Dermestes sp. & 0,000 & 0,000 & 0,404 & 7,238 & 8,046 \\
\hline & Histeridae & Hister sp. & 0,000 & 0,000 & 0,404 & 1,405 & 0,000 \\
\hline & Scarabaeidae & Onthophagus sp. & 0,000 & 0,000 & 0,000 & 0,141 & 0,000 \\
\hline & Chrysomelidae & Unidentified & 0,000 & 0,000 & 0,000 & 0,070 & 0,000 \\
\hline
\end{tabular}

Remains (Day 16 through Day 27).

The carcass did not undergo many changes in this stage. The body temperature oscillated 2 to 3 degrees higher than the ambient temperature (Fig.1). The weight went from $3 \mathrm{Kg}$ to $1 \mathrm{Kg}$ (Fig. 2).

The different species that were found in this stage are: $S$. nigriceps $\mathrm{L} 2$ and $\mathrm{L} 3, O$. aenescens $\mathrm{L} 1, \mathrm{~L} 2$ and $\mathrm{L} 3, O$. discicolle larvae and Dermestes sp. and Hister sp. adults (Table IV).

Sucession Matrix (Presence-Absence).

The sucession matrix was created based on larvae of the following dipteran species: L. eximia, H. semidiaphana, C. macellaria, C. megacephala, C. albiceps, C. verena, $M$. domestica, $O$. aenescens and $S$. nigriceps; and adults of Coleoptera species Anotylus sp., O. discicolle (larvae and adult), Paederomimus sp., Philonthus sp., Dermestes sp., Hister sp. and Ambodina sp., which were the most representatives species of the succession and also were the colonizing species (Table IV).

\section{DISCUSSION}

Five stages of decay were observed: fresh, bloated, active, advanced, and remains. Their delimitation was done considering the changes in the carcass's appearance, the body temperature and the presence of insects that marked these types of processes. Even so, the body temperature throughout the entire process oscillated almost with the ambient temperature. Also, the decomposition features for each of the stages were not clearly observed, which made it difficult to define the exact transition between the stages of decomposition. This was probably caused by the almost constant rain regime during the collections in October and November, the period of concentrated rain in the study area, suggesting that the duration of each stage can depends on the ambient conditions, which can affect the rate of decomposition (Schowalter 2000).

In tropical ecosystems, the rainfall pattern is more variable (Mavárez-Cardozo et al. 2005) and one of the factors that retard the decomposition is water, because body heat is lost twice as quickly as in the air (Smith 1986). Likewise, the insects associated with the corpse die by drowning affecting time of decomposition.

Davis \& Goff (2000) concluded that water is a key factor in the differences between intertidal and terrestrial decomposition, demonstrating that it limits the access of carrion arthropods and reinforcing the hypothesis that the decomposition patterns and the organisms found in bodies vary according to the habitat, temperature and degree of exposure 
Table III. Percentage of immature dipterans and coleopterans collected in exposed carcass in Colombia's Andean Coffee Region at each stage of decomposition.

\begin{tabular}{|c|c|c|c|c|c|c|c|}
\hline Order & Family & Specie & $\begin{array}{l}\text { Fresh } \\
\text { (Day 0) }\end{array}$ & $\begin{array}{l}\text { Bloated } \\
\text { (Day 1-5) }\end{array}$ & $\begin{array}{c}\text { Active } \\
\text { (Day 6-9) }\end{array}$ & $\begin{array}{c}\text { Advanced } \\
\text { (Day 10-15) }\end{array}$ & $\begin{array}{c}\text { Remains } \\
\text { (Day 16-26) }\end{array}$ \\
\hline \multirow[t]{10}{*}{ Diptera } & Calliphoridae & Lucilia sp. (Larvae I) & 63,560 & 3,711 & 0,000 & 0,000 & 0,000 \\
\hline & & Lucilia eximia & 36,905 & 57,732 & 1,816 & 3,654 & 0,000 \\
\hline & & Cochliomyia macellaria & 0,000 & 15,463 & 68,416 & 35,067 & 0,000 \\
\hline & & Chrysomya albiceps & 0,000 & 6,186 & 9,788 & 1,195 & 0,000 \\
\hline & & Hemilucilia semidiaphana & 0,000 & 1,237 & 1,312 & 0,141 & 0,000 \\
\hline & & Chrysomya megacephala & 0,000 & 0,206 & 0,000 & 0,000 & 0,000 \\
\hline & & Compsomyiops verena & 0,000 & 0 & 0,404 & 0,070 & 0,000 \\
\hline & Muscidae & Ophyra aenescens & 0,000 & 0,000 & 0,605 & 30,850 & 83,908 \\
\hline & & Musca domestica & 0,000 & 0,000 & 0,101 & 0,000 & 0,000 \\
\hline & Fanniidae & Fannia sp. & 0,000 & 0,000 & 0,000 & 0,141 & 0,000 \\
\hline Coleoptera & Silphidae & Oxelytrum discicolle & 0,000 & 0,206 & 0,000 & 0,141 & 0,000 \\
\hline
\end{tabular}

to water. This fact may make these types of decomposition incomparable with decomposition occurring in other ambient conditions (e.g. dry season).

The fresh stage lasted one day, differing from most successional studies conducted in Colombia, where the duration was from 2 to 4 days (Martínez et al. 2007; Segura et al. 2009; Camacho 2005). Nonetheless, the duration of the other decomposition stages (bloating -5 days, active -4 days, advanced -5 days and remains -11 days) are within the range of days observed in those studies.

Lucilia eximia, C. macellaria and Bithoracochaeta sp. were the first species to colonize the carcass. However, $L$. eximia was the first to oviposit on the carcass, approximately 10 minutes after death, initially in the mouth and, subsequently, on the back and face. These results differ from those obtained in Medellin, where Phaenicia sericata was the first species to appear (Wolff et al. 2001; Pérez et al. 2005); Calliphora nigribasis and Compsomyiops verena in the Chingaza National Park in highlands ecosystem (Martínez et al. 2007); Calliphora vicina in Bogotá (Camacho 2005) and C. macellaria in Sucre (D. Grisales, unpublished data).

Of the species found here, some were already reported in Colombia associated with decaying bodies and for the same life zone of the study area, including $L$. eximia as a primary colonizer; $C$. macellaria as a secondary species, arriving at the bodies after these have been colonized by other species and $H$. semidiaphana, collected in carcasses exposed in the bloated through the advanced stage (Wolff \& Vélez 2007), reports that are consistent with the behavior of these species in this study.

From the bloated through the advanced stage, L. eximia, C. macellaria, C. albiceps, and $H$. semidiaphana, in that order of importance, were mainly responsible for the removal of the carcass's tissues, with a great amount of $C$. macellaria found in the advanced stage, together with Ophyra aenescens. This muscid species was the dominant species in the remains stage, a finding not recorded in forensic entomology studies in Colombia, where the indicator species of this stage were beetles Dermestids, Histerids, Staphylinidae and Silphidae (Wolff et al. 2001; Segura et al. 2009); Dipterans Piophila foveolata (Piophilidae) (Pérez et al. 2005)and Leptocera sp. (Sphaeroceridae) (Martínez et al. 2007). This fact perhaps is due to the food preferences of this species, which feeds on the mucilaginous material (BOD) usually present in the advanced stage, but in this case it was more evident in the stage of remains.

In this study the carcass took 27 days to decompose. In the study conducted by Gomes et al. (2009), where the model and the study area were similar, the decomposition occurred in 28 days during the rainy season, while in studies conducted in the dry season, the total decomposition time was between 83 days (Martínez et al. 2007) and 45 days (Carvalho \& Linhares 2001), depending on the altitude, which influences both the humidity and the diversity of the insects.

Among the forensically important beetles, Anotylus sp., Paederomimus sp. and Philonthus sp., (Staphylinidae) adults were collected in this study and were also reported by Nuorteva (1977) in Finland. The predators Ambodina sp. aff. (Staphylinidae), Dermestes sp. (Dermestidae), Hister sp. (Histeridae) and $O$. discicolle (Silphidae) arrived at the carcass once there were larvae and other insects to feed on. The most representatives were Anotylus sp. and $O$. discicolle, but only the latter, the most abundant in the process, was collected both as immatures and adults. This species is predatory and necrophagous, found feeding mainly under the carcass and in the skull. The feeding habits of adult and immature specimens of some species of necrophagous beetles differ, due to the competition with the Diptera that are more agile at colonizing a carcass quickly. Necrophagous beetles prefer to arrive at the carcass later, in drier stages, and the predator ones have the strategy of arriving before the fly larvae migrate far from the body (Olivera-Costa 2007). In a study conducted in the city of Curitiba (Brazil), where the fauna of Coleoptera was collected from a pig carcass (Mise et al. 2007), O. discicolle was found from the bloated phase until the end of the descomposition. This observation coincides 
Table IV. Occurrence Matrix (presence-absence). 0: absence; 1: presence: F: fresh; L: larvae; A: adult; L1: larvae 1; L2: larvae 2; L3: larvae 3; Pp: pre-pupae; P: pupae. Gray boxes show the first occurrence of the species in each stage of decomposition.

\begin{tabular}{|c|c|c|c|c|c|c|c|c|c|c|c|c|c|c|c|c|c|c|c|c|c|c|c|c|c|c|}
\hline & \multirow{3}{*}{ Days } & \multirow{2}{*}{$\frac{F}{0}$} & \multicolumn{4}{|c|}{ Bloated } & \multicolumn{4}{|c|}{ Active } & \multicolumn{6}{|c|}{ Advanced } & \multicolumn{10}{|c|}{ Remains } \\
\hline & & & 1 & 3 & 4 & 5 & 6 & 7 & 8 & 0 & 10 & 11 & 12 & 13 & 14 & 15 & 16 & 17 & 18 & 21 & 22 & 23 & & 25 & 26 & \\
\hline & & & L1 L2 $\mid A L 1$ & $11 \angle 2 \angle 3 \mid A \angle 2 \angle 3\llcorner A$ & QL1 L2 L 13 & AL1L2L3 & $A\llcorner 1\llcorner 2 L 3$ & \begin{tabular}{l|l|l|l|}
$13 L 1 L 2 L 3 A$ \\
\end{tabular} & $A L 1 L 2 \angle 3 \mid A$ & AL1L2L3 & AL1L2L3 LP & AL2L3]A & \begin{tabular}{|l|l|}
$A L 2 L 3 P$ & $A L$ \\
\end{tabular} & $\angle 1 L 2 \angle 3 P P P$ & ALL L3P & $P \mid A \angle 2 L 3$. & $A \angle 2 \angle 3 \mathrm{P}$ & $|P p| A L 1 \angle 2 \angle 3 \mid A$ & $A \angle 1\llcorner 2\llcorner 3 P$ & $A\llcorner 2 \angle 3 \mid A$ & $\mathrm{A}\llcorner 2 \mathrm{L3}$ & AL1L2 L3 P & $3 P[2\llcorner 3 \mid A$ & $13 \mid A L 1$ L 3$] A$ & $\angle 3 \mid A$ L1 L2 L3 A & $A \angle 2 \angle 3 L$ \\
\hline \multirow{17}{*}{ Species } & Luclila eximia & 11 & 1101 & 1101100 & 0111 & 0011 & 0111 & 101110 & 00010 & 0001 & 0001000 & 0000 & 000000 & 000100 & 0000 & 0000 & 000 & 100000 & 00000 & 0000 & 000 & 00001 & & 00000 & 000000 & 0000 \\
\hline & Anotylus sp. & 00 & 0010 & 00010000 & 0000 & 1000 & 1000 & 010000 & 00000 & 0000 & 0000000 & 0000 & 000010 & 1000000 & 00000 & 0100 & 000 & 00000000 & 00000 & 0000 & 000 & 000000 & 000 & 00000 & 00000000 & 00000 \\
\hline & Hemilucilia semidiaphana & 00 & 0000 & 1001000 & 0011 & 0011 & 0011 & 100110 & 00110 & 0011 & 0001000 & 0010 & 001001 & 101110 & 0000 & 0000 & 000 & 00000000 & 00000 & 0000 & 000 & 000000 & & 00000 & 00000000 & 00000 \\
\hline & Oxelytum disc & 00 & 0000 & 00000011 & 1000 & 0000 & 0000 & 000001 & 10001 & 1000 & 100010 & 1001 & 100 & 0 & 1000 & 0100 & 100 & 0000001 & 10000 & 1001 & 100 & 000 & & 0000 & 00000000 & 00001 \\
\hline & Iomimus sp. & 00 & 0000 & 00000001 & 1000 & 0000 & 1000 & 000000 & 00001 & 1000 & 1000 & 0000 & 000000 & 00 & 0000 & 0000 & 000 & 00000000 & 00000 & 0000 & 000 & 000000 & 000 & 0000 & 0000000 & 0000 \\
\hline & omyia macellaria & 00 & 00000 & 00000000 & 0111 & 0110 & 0111 & 101110 & 01110 & 0111 & 101 & 0110 & 011100 & 001 & 0101 & 1000 & 000 & 00000000 & 000001 & 0000 & 000 & 000 & 000 & 0000 & 00000000 & 0000 \\
\hline & phale & 00 & 0000 & 00000000 & 0010 & 0001 & 0000 & 000000 & 00000 & 0000 & 000 & 00 & & 1000 & 0000 & 0000 & 000 & 00000000 & 000 & 0000 & 000 & 000 & 000 & 0000 & 00000000 & 0000 \\
\hline & scep & 00 & 0000 & 00000000 & 0000 & 0010 & 00001 & 101100 & 00110 & 0001 & 101 & 00 & & & 0000 & 0000 & 000 & 00000000 & 00000 & 0000 & 000 & 000 & 000 & 0000 & 0000000 & 0000 \\
\hline & Philonhtus sp. & 00 & 0000 & 00000000 & 0000 & 0000 & 00000 & 010000 & 00000 & 00000 & 100 & 10 & 100010 & 000 & 1000 & 0000 & 100 & 0100000 & 00000 & 00001 & 100 & 00000 & 000 & 0000 & 00000000 & 0000 \\
\hline & ps & 00 & 0000 & 00000000 & 0000 & 0000 & 0000 & 000000 & 00010 & 00001 & 000 & & 001000 & 000000 & 0000 & 0000 & 000 & 00000000 & 00000 & 0000 & 000 & 000000 & 000 & 0000 & 00000000 & 0000 \\
\hline & sp. & 00 & 0000 & 000000 & 00000 & 0000 & 00000 & 000000 & 0000 & 1000 & 1000 & 1001 & 100010 & 000000 & 1000 & 0100 & 100 & 010001 & 10000 & 1001 & 100 & 10000 & 000 & 0100 & 0100001 & 1000 \\
\hline & 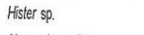 & 00 & 0000 & 000000 & 000 & 0000 & 0000 & 000000 & 00001 & 1000 & 100000 & 0001 & 100010 & 000000 & 1000 & 0100 & 100 & 0100001 & 10000 & 0001 & 100 & 000000 & & & & 0000 \\
\hline & done & 00 & 0000 & 00000000 & 0000 & 0000 & 0000 & 000000 & 00000 & 0001 & 000000 & 0000 & 00000 & & 0000 & 00000 & 000 & 0000000 & 00000 & 0000 & 000 & 00000 & & & 00000000 & 0000 \\
\hline & scens & 00 & 00000 & 00000000 & 0000 & 0000 & 0000 & 000000 & 00000 & 0001 & 011100 & 0110 & & & 0110 & 0011 & 011 & 001110 & 01110 & 0110 & 011 & 01110 & & & 100110 & 0010 \\
\hline & Ambodina sp. & 00 & 0000 & 00000000 & 0000 & 0000 & 00000 & 000000 & 00000 & 0000 & 100000 & & 000000 & & 0000 & 0100 & 100 & 0100001 & 10000 & 0000 & 000 & 000000 & 000 & 000 & 0000000 & 0000 \\
\hline & Fanniasp. & 00 & 0000 & 00000000 & 0000 & 0000 & 0000 & 000000 & 00000 & 0000 & 000100 & 0000 & 000000 & 000000 & 0000 & 0000 & 000 & 0000000 & 00000 & 0000 & 000 & 000000 & 000 & & 0000000 & 0000 \\
\hline & Stearibia nigiceps & 00 & 000 & 000000000 & 000 & 00000 & 0000 & 00000000 & 00000 & 00000 & 000000 & 0000 & 000000 & 000000 & 0000 & 00000 & 0000 & 0000000 & 00000 & 0000 & 000 & 000000 & & & & 011 \\
\hline
\end{tabular}

with this study and differs from what was found by Wolff et al. (2001) in Colombia, where this beetle was found from the active stage until remains. In this study oviposition sites of $O$. discicolle were found under the skull of the carcass, where they could be observed feeding both as adult and larva. Likewise, Mise et al. (2007) found 2 multivoltine species of Anotylus throughout the entire year of collection, from the fresh stage to the end of the descomposition.

Colonizing species may be established based on their initial presence; the combination of existing species is useful to know the state of decomposition of a corpse. In the study region, the colonizing Diptera species are: L. eximia (fresh); H. semidiaphana, C. macellaria and C. megacephala (bloated); C. albiceps, C. verena, O. aenescens and $M$. domestica (active); Fannia sp. (advanced) and S. nigriceps (remains); and colonizing Coleptera species are: Anotylus sp., O. discicolle, Paederomimus sp. (bloated); Philonthus sp., Dermestes sp., Hister sp. (active); Ambodina sp. (advanced).

Regardless of the precise delimitation of the decomposition stages, replicating the particular experimental conditions of each ecosystem, makes it easier to assign probabilities of presence of a taxon at a point of the sucession and a certain assembling in species composition per unit of time after death (Wells \& Greenberg 1994), making succession studies important for developing and implementing effective tools for issuing reliable post-mortem intervals, as well as for obtaining knowledge of forensically important species in each ecosystem.

The succession of necrophagous insects found in Colombia's Andean region (coffee zone), offers important data to create an occurrence matrix (presence-ausence). This matriz can be used to establish a post-mortem interval in cases of corpses of humans and animals exposed to similar environmental conditions.

Acknowledgements. To the Universidad Cooperativa de Colombia, Medellín branch, for funding the project. To Dr. Marta Wolff for her scientific help throughout this project and to the Laboratorio de Colecciones Entomológicas de la Universidad de Antioquia. To Olmedo Ochoa and family for the use of the study area (Finca La Acuarela). To Luz Adriana García for collaborating in the collection. To Dr. Jonny Duque for his contribution in preparing this article. D. Grisales is fellowship of CAPES /CNPq - IEL Nacional - Brasil.

\section{REFERENCES}

Aguilar P. M. \& Ch. J. O. Rangel. 1994. Clima del Parque Regional Natural Ucumarí Sectores Aledaños, p. 39-56. In: Ch. J. O. Rangel. UCUMARI Un caso típico de la diversidad biótica andina. Pereira, CARDER, Universidad Nacional de Colombia, 200 p.

Anderson, G. S. \& S. L. Van Laerhoven. 1996. Initial Studies on Insects Succession on Carrion in Southwestern British Columbia. Journal of Forensic Sciences 41: 617-625.

Anderson, G. 2001. Insect Succession on Carrion and its Relationship to Determining Time of Death, p. 143-176. In: Byrd, J. \& J. Castner (ed.). Forensic Entomology. The Utility of Arthropods in Legal Investigations. Boca Ratón, CRC press, 418 p.

Barreto, M.; M. E. Burbano \& P. Barreto. 2002. Flies (Calliphoridae, Muscidae) and Beetles (Silphidae) from Human Cadavers in Cali, Colombia. Memórias do Instituto Oswaldo Cruz 97: 137-138.

Benecke, M. 1998. Six Forensic Entomology Cases: Description and Commentary. Journal of Forensic Science 43: 797-805.

Borror, D.; C. Triplehorn \& N. Johnson. 1989. An Introduction to the Study of Insects. Philadelphia, Saunders College Publishing, 875 p.

Camacho G. P. \& W. Usaquén. 2004. Ciclo de vida de Lucilia sericata (Diptera: Calliphoridae) como primera especie colonizadora presente en hígado humano realizado en el Instituto Nacional de Medicina Legal y Ciencias Forenses. Bogotá 2000. Revista Instituto de Medicina Legal y Ciencias Forenses 18: 31-36.

Camacho G. P. 2005. Sucesion de la entomofauna cadavérica y ciclo vital de Calliphora vicina (Diptera: Calliphoridae) como primera especie colonizadora, utilizando cerdo blanco (Sus scrofa) en Bogotá. Revista Colombiana de Entomologia 31: 189-197.

Carvalho, C. J. B. de (ed.). 2002. Muscidae (Diptera) of the Neotropical Region: Taxonomy. Curitiba, Editora UFPR, $287 \mathrm{p}$.

Carvalho, L. M. L. \& A. X. Linhares. 2001. Seasonality of Insect Succession and Pig Carcass Decomposition in a Natural Forest Area in Southeastern Brazil. Journal of Forensic Science 46: 604-608.

Davis, J. B. \& M. L. Goff. 2000. Decomposition Patterns in Terrestrial and Intertidal Habitats on Oahu Island and Coconut Island, Hawaii. Journal of Forensic Science 45: 836-842.

Dear, J. 1985. A Revision of the New World Chrysomyini (Diptera: Calliphoridae). Revista Brasileira de Zoologia 3: 109-169.

Gomes, L.; G. Gomes \& I. C. Desuó. 2009. A Preliminary Study of Insect Fauna on Pig Carcasses Located in Sugarcane in Winter in Southeastern Brazil. Medical and Veterinary Entomology 23: 155-159.

Greenberg, B. \& M. Szyska. 1984. Immature Stages and Biology of Fifteen Species of Peruvian Calliphoridae (Diptera). Annals of the Entomological Society of America 77: 488-517.

Hanski, I. \& Y. Cambefort. 1991. Dung Beetle Ecology. New Jersey, 
Princeton University Press, 500 p.

Holdridge, L. 1987. Ecología basada en zonas de vida. San José, Instituto Interamericano de Cooperación para la Agricultura IICA, $216 \mathrm{p}$.

LaMotte, L. \& J. Wells. 2000. p -Values for Postmortem Intervals from Arthropod Succession Data. Journal of Agricultural, Biological and Environmental Statistics 5: 58-68.

Liu, D. \& B. Greenberg. 1989. Immature Stages of Some Flies of Forensic Importance. Annals of the Entomological Society of America 82: $80-93$.

Martínez, E.; P. Duque \& M. Wolff. 2007. Succession Pattern of Carrionfeeding Insects in Páramo, Colombia. Forensic Science International 166: $182-189$.

Mavárez-Cardozo M. G.; A. L. Espina de Fereira; F. A. Barrios-Ferrer \& J. L. Fereira-Paz. 2005. La Entomología Forense y el Neotrópico. Cuadernos de Medicina Forense 11: 23-33.

McAlpine, J.; B. Peterson; G. Shewell; H. Teskey; J. Vockeroth \& D. Wood. 1981. Manual of Nearctic Diptera. Volume 1. Quebec, Minister of Supply and Services, $674 \mathrm{p}$.

McAlpine, J.; B. Peterson; G. Shewell; H. Teskey; J. Vockeroth \& D. Wood. 1987. Manual of Nearctic Diptera. Volume 2. Quebec, Minister of Supply and Services, $674 \mathrm{p}$.

Mise, K. M.; L. M. de Almeida \& M. O. Moura. 2007. Levantamento da fauna de Coleoptera que habita a carcaça de Sus scrofa L., em Curitiba, Paraná. Revista Brasileira de Entomologia 51: 358-368.

Nuorteva, P. 1977. Sarcosaprophagous Insects as Forensic Indicators, p. 1072-1095. In: Tedeschi, C. G.; N. G. Eckert \& L. G. Tedeschi (Eds): Forensic Medicine - Study in Trauma and Environmental Hazards. Vol.11: Physical Trauma. Pennsylvania, Saunders and Co. $1637 \mathrm{p}$.

Oliveira-Costa, J. 2007. Entomologia Forense: Quando os insetos são vestígios. $\mathbf{2}^{\mathrm{a}}$ edição, (Tratado de perícias criminalísticas; v.8). Campinas, Millennium Editora, $456 \mathrm{p}$.

Pérez, S.; P. Duque \& M. Wolff. 2005. Successional Behavior and Occurrence Matrix of Carrion-Associated Arthropods in the Urban Area of Medellin, Colombia. Journal of Forensic Science 50: 448-453.

Peñuela A. L. S. 2005. El papel del bioanalista forense frente al sistema acusatorio. Medellín, Señal Editora, 345 p.

Queiroz, S. \& C. J. B. de Carvalho. 1987. Chave Pictórica e Descrições de Larvas de $3^{\circ}$ Instar de Diptera (Calliphoridae, Muscidae e Fanniidae) em Vazadouros de Resíduos Sólidos Domésticos em Curitiba, Paraná. Anais da Sociedade Entomologica do Brasil 6: 265-288.
Segura, N. A.; W. Usaquén; M. C. Sánchez; L. Chuaire \& F. Bello. 2009. Succession pattern of cadaverous entomofauna in a semi-rural area of Bogotá, Colombia. Forensic Science International 187: 66-72.

Smith, K. 1986. A Manual of Forensic Entomology. London, The Trustees of the British Museum (Natural History) and Ithaca, University Press, $475 \mathrm{p}$.

Schoenly, K.; M. Goff, \& M. Early. 1992. A Basic Algorithm for Calculating the Postmortem Interval from Arthropod Successional Data. Journal of Forensic Science 37: 808-823.

Schowalter, T. 2000. Insect Ecology. An Ecosystem Approach. San Diego, Academic Press, $483 \mathrm{p}$.

Stehr, F. 1987. Immature Insects. Volume 2. Dubuque, Kendall/Hunt Publishing Company, $974 \mathrm{p}$.

Vélez, M. C \& M. Wolff. 2008. Rearing five species of Diptera (Calliphoridae) of forensic importance in Colombia in semicontrolled field conditions. Papéis Avulsos de Zoologia 48: 41-47.

White, R. 1983. A Field Guide to the Beetles of North America. New York, Peterson Field Guides series, 368 p.

Wells, J.; J. Byrd \& T. Tantawi. 1999. Key to Third-Instar Chrysomyinae (Diptera: Calliphoridae) from Carrion in the Continental United States. Journal of Medical Entomology 36: 638-641.

Wells, J. \& B. Greenberg. 1994. Effect of the Red Imported Fire Ant (Hymenoptera: Formicidae) and Carcass Type on the Daily Occurrence of Post Feeding Carrion-Fly Larvae (diptera: calliphoridae, Sarcophagidae). Journal of Medical Entomology 31: 171-174.

Wolff, M; A. Uribe; A. Ortiz \& P. Duque. 2001. A Preliminary Study of Forensic Entomology in Medellin, Colombia. Forensic Science International. 120: 53-59.

Wolff, M.; A. Builes; G. Zapata; G. Morales \& M. Benecke. 2004. Detection of Parathion (0,0-diethyl 0-(4nitrophenyl) phosphorothioate) by HPLC in Insects of Forensic Importance in Medellín, Colombia. Anil Aggrawal's Internet Journal of Forensic Medicine and Toxicology 5: 6-11.

Wolff, M.; A. Builes; G. Zapata; G. Morales \& M. Benecke. 2006. Detección y cuantificación de Propoxur en la sucesión de insectos de importancia médico-legal. Revista Colombiana de Entomología 32: 159-164.

Wolff, M. \& C. Vélez. 2007. Calliphoridae (Diptera) de Importancia Forense en Colombia. Anotaciones sobre su Comportamiento y Distribución, p. 88-98. In: Memorias XXXIV Congreso de Entomología. Sociedad Colombiana de Entomología. SOCOLEN, 2007. Alpha Impresores. $197 \mathrm{p}$. 